\title{
Mangrove reforestation in Vietnam: the effect of sediment physicochemical properties on nutrient cycling
}

\author{
J. F. Oxmann • Q. H. Pham • L. Schwendenmann • \\ J. M. Stellman • R. J. Lara
}

Received: 10 November 2008 / Accepted: 14 April 2009/Published online: 19 May 2009

(C) Springer Science + Business Media B.V. 2009

\begin{abstract}
Sediment physicochemical properties most likely control the reforestation success on degraded mangrove sites. Our objectives were (1) to determine the nutritional status of reforested mangrove stands; (2) to investigate the effects of the redox potential (Eh) and $\mathrm{pH}$ on phosphorus $(\mathrm{P})$ and nitrogen $(\mathrm{N})$ cycling; and (3) to assess the effect of $\mathrm{pH}$ on $\mathrm{P}$ speciation. Five transects were studied in replanted stands of the Saigon River Delta, Vietnam. Spatial gradients of sediment $\mathrm{Eh}$ and $\mathrm{pH}$ were affected by the
\end{abstract}

Responsible Editor: John McPherson Cheeseman.

J. F. Oxmann $(\bowtie) \cdot$ R. J. Lara

Department of Biogeochemistry,

Center for Tropical Marine Ecology,

Fahrenheitstr. 6,

28359 Bremen, Germany

e-mail: julian.oxmann@zmt-bremen.de

Q. H. Pham

Department of Botany and Ecology,

University of Natural Sciences,

Nguyen Van Cu Str. 227, Dist. 5,

Ho Chi Minh City, Vietnam

L. Schwendenmann

Tropical Silviculture and Forest Ecology,

Burckhardt-Institute, University of Göttingen,

Buesgenweg 1,

37077 Göttingen, Germany

J. M. Stellman

Department of Environmental and Occupational Health, Downstate Medical Center, State University of New York, Brooklyn, NY 11203, USA tidal regime and pyrite oxidation. Sediment Al/Fe-P correlated with Eh or $\mathrm{pH}$, depending on the sediment layer, whereas Ca-P, Morgan-P (available P) and leaf $\mathrm{P}$ were influenced by the $\mathrm{pH}$. The highest concentrations of $\mathrm{Al} / \mathrm{Fe}-\mathrm{P}$ were recorded at $\mathrm{pH} 6.5$ probably due to adsorption effects. Sediment Ca-P increased strongly at $\mathrm{pH}$ below 4 and above 6 , reflecting the different $\mathrm{pH}$ dependent solubilities of individual $\mathrm{Ca}-\mathrm{P}$ mineral species as shown by a newly developed method for $\mathrm{P}$ species quantification. A strong increase of available $\mathrm{P}$ and leaf $\mathrm{P}$ above $\mathrm{pH}$ 6, and positive correlations of available $\mathrm{P}$ vs Ca-P $(P<0.001)$ and leaf $\mathrm{P}(P=0.004)$ suggest that the Morgan's reagent for available $P$ determination solubilizes mainly thermodynamically less stable Ca-P compounds, which seem to fuel $\mathrm{P}$ plant uptake. Since foliar and sediment N:P ratios were influenced mainly by $\mathrm{pH}$, shifts in $\mathrm{pH}$ likely cause limitation transitions. Overall, sediment $\mathrm{pH}$ rather than Eh was found to control the nutrient status.

Keywords Calcium phosphate minerals .

Nutrient availability · Phosphorus limitation .

Sediment acidification $\cdot$ Redox potential and $\mathrm{pH}$

\section{Introduction}

Mangroves act as a protection for the coastal environment, provide basic subsistence resources for the local population, and support the sustainability of commercial fisheries. Conversion of mangroves to agricultural 
use is often not effective, because these wetlands exhibit a high potential for sediment acidification by pyrite $\left(\mathrm{FeS}_{2}\right)$ oxidation (Dent 1986). Moreover, agricultural systems of free tidal irrigation are limited to areas that carry sufficient fresh water during the rainy season to leach accumulated salt (Hart 1959). If large mangrove areas have been destroyed, as for example in Vietnam during the Second Indochina War, there is no alternative other than reforestation.

One of the main reasons why mangrove reforestation fails is due to previously induced changes in the sediment properties that occur when sediments are no longer vegetated. In mangrove sediments, iron sulphides (FeS) form under undisturbed conditions by sulphate reduction through continuous sulphate and organic matter (OM) supply according to the equation

$$
\begin{aligned}
& 4 \mathrm{Fe}(\mathrm{OH})_{3}+4 \mathrm{CaSO}_{4}+9 \mathrm{CH}_{2} \mathrm{O} \\
& \quad \rightarrow 4 \mathrm{FeS}+\mathrm{Ca}\left(\mathrm{HCO}_{3}\right)_{2}+\mathrm{CO}_{2}+11 \mathrm{H}_{2} \mathrm{O} .
\end{aligned}
$$

These sulphides transform into more stable polysulphides, mainly $\mathrm{FeS}_{2}$. The lack of $\mathrm{OM}$ input through litterfall diminishes microbial activity, reduces the electron pressure in the sediments, and redox potential (Eh) rises as oxygen penetrates the sediment. As a consequence, the formation of sulphuric acid by the oxidation of iron sulphides according to the equation

$$
\begin{aligned}
& \mathrm{FeS}_{2}+15 / 4 \mathrm{O}_{2}+7 / 2 \mathrm{H}_{2} \mathrm{O} \\
& \rightarrow \mathrm{Fe}(\mathrm{OH})_{3}+2 \mathrm{SO}_{4}^{2-}+4 \mathrm{H}^{+}
\end{aligned}
$$

drastically lowers the sediment $\mathrm{pH}$ of unvegetated flats. Acid fluxes into rivers (Macdonald et al. 2007) and leaching of potentially toxic metals (Roos and Åström 2006) occur. The low productivity of the socalled acid sulphate soils can be attributed mainly to toxicity of aluminium and to nutrient deficiencies, especially of phosphorus (P). Restricted availability of $\mathrm{P}$ at low $\mathrm{pH}$ may arise from (1) the formation of relatively insoluble Al-P or Fe-P; (2) the absence of thermodynamically less stable Ca-P species; (3) leaching of $\mathrm{P}$ through enhanced liberation of $\mathrm{P}$ caused by high temporary $\mathrm{pH}$ changes, e.g., by flooding with seawater; (4) restricted P release through OM decomposition due to unfavourable conditions for microorganisms; and (5) less $\mathrm{P}$ uptake by mycorrhiza at extreme acidity.
While land reclamation strategies in the tropics have been developed for acidified agricultural systems, such as applications of fertilizers or lime (Dent and Turner 1981; Dost and van Breemen 1982), corresponding field trials for mangroves are scarce.

Fertilization experiments in mangroves have shown that nitrogen $(\mathrm{N})$ limitation at fringe sites may shift to P limitation in dwarf forests (Boto and Wellington 1983; Feller et al. 2003a). While other studies carried out in mangrove areas both agreed (Feller et al. 2003b) and disagreed (Feller 1995; Koch and Snedaker 1997; Naidoo 2006) with the predominant observation of $\mathrm{N}$ limitation in different coastal and estuarine environments, the question of $\mathrm{P}$ or $\mathrm{N}$ limitation in mangroves remains unclear. However, the cited fertilization experiments focused on redoxrelated nutrient supply and environmental stressors as possible factors for changes in limitation. These studies did not investigate the effect of sediment $\mathrm{pH}$ on nutrient deficiencies and limitation shifts. Assuming the $\mathrm{pH}$ to be the driving force for nutrient supply, sediment Eh and hydrological characteristics would affect this system indirectly by their effect on $\mathrm{pH}$.

The effect of Eh on P cycling has been subject to a number of studies, because reduction of soils or sediments is generally thought to increase available $\mathrm{P}$ levels. Nevertheless, transformation processes during reduction and their effects on $\mathrm{P}$ solubility are still a matter of debate (Golterman 2001), while the effect of the sediment $\mathrm{pH}$ is poorly investigated. Controversial results of increased or decreased $\mathrm{P}$ solubility caused by submergence may result partly from $\mathrm{pH}$ changes. Nutrient levels and availability depend on substrate $\mathrm{pH}$ values. A strong $\mathrm{pH}$ dependency is expected particularly for $\mathrm{P}$ content and speciation, because the solubility of particular phosphate minerals is driven predominantly by the pH (Lindsay 1979; Lindsay et al. 1989). The interactions of the tidal regime, geomorphologic properties and geochemical characteristics in coastal regions cause gradients in the sediment $\mathrm{pH}$ that likely have strong impacts on nutrient distribution patterns and resulting limitation transitions.

The specific objectives of our study were (1) to determine the nutritional status of reforested mangrove stands, which present a gradient from strongly acidic to alkaline sediments; (2) to investigate the effects of the Eh and $\mathrm{pH}$ on $\mathrm{P}$ and $\mathrm{N}$ cycling; and (3) to assess the effect of the $\mathrm{pH}$ on $\mathrm{P}$ speciation. Since $\mathrm{P}$ seems to be the limiting nutrient for plant growth on 
acidified sediments (e.g., Dent 1986), we focused especially on the effect of the sediment $\mathrm{pH}$ on $\mathrm{P}$ cycling. A deeper insight into $\mathrm{P}$ speciation was enabled using a recently developed conversionextraction method (CONVEX, Oxmann et al. 2008). Assessment of the nutritional status and investigation of its control are necessary for developing successful mangrove restoration strategies.

\section{Materials and methods}

Study area

The study was conducted in the UNESCO Can Gio Mangrove Biosphere Reserve (CGMBR; $10^{\circ} 22^{\prime}$ to $10^{\circ} 40^{\prime} \mathrm{N}, 106^{\circ} 46^{\prime}$ to $107^{\circ} 01^{\prime} \mathrm{E}$ ) of the Saigon River Delta, southern Vietnam (Fig. 1a-e). The CGMBR covers the main part of the delta (Fig. 1a, shaded dark-grey). In the study area, mangrove stands had been destroyed by the dispersal of herbicide mixtures during the Second Indochina War. The codenamed Rung Sat Zone within the Saigon River Delta was one of the most heavily sprayed areas in Vietnam. Using a recently developed Geographic Information System that incorporates extensive military data resources of spray missions during the Second Indochina War (Stellman 2003a, b), we determined that at least $3,776,5601$ herbicidal agents were sprayed by military aircraft in the delta. The map presented in Fig. 1a shows the high density of spray paths. At the selected sites, herbicide dosages for the complete destruction of the huge and dense mangrove vegetation were ca. 100 times higher (ca. 50-100 1 ha $^{-1}$; see Table 1) than the amounts used for civil purposes (ca. 0.5-1.0 1 2,4,5-trichlorophenoxyacetic acid $\mathrm{ha}^{-1}$ ). Field observations, forestry department records (V.N. Nam, personal communication) and a comparison of the spray map (Fig. 1a) with satellite remote sensing (Hirose et al. 2004) indicate that virtually no virgin forest remained within the sprayed parts of the delta. In some areas, sediments turned to acid sulphate conditions due to the induced oxidation, and remain in this condition even today. After the war, reforestation was started in the CGMBR, which has continued to the present day, using predominantly seeds and saplings of Rhizophora apiculata. At the study sites, reforestation took place between 1978 and 1986 (Table 1).

\section{Station selection}

Based on a pre-survey, five transects were established at an acid sulphate site and a control site including 24 sampling stations at 11 sectors (Fig. 1b-e). The station-ID is given by the transect number followed by a letter that refers to the forest sector (see Fig. 1c). As nutrient dynamics in mangroves depend strongly on inundation frequencies (Lara et al. 2009), all transects were established perpendicular to the Dong Tranh River to investigate the effect of topographic elevation, and therefore of the inundation regime, on sediment physicochemical parameters and on distribution patterns of $\mathrm{P}$ and $\mathrm{N}$ in sediment and leaves. The control site (Fig. 1d) and the acid sulphate site (Fig. 1e) were chosen to characterize the effects of acidification on nutrient cycling and plant growth by comparison of sectors with similar inundation frequencies but different sediment $\mathrm{pH}$ values. The three transects within the control site were established to investigate a geochemically typical mangrove site with slightly acidic to alkaline sediment $\mathrm{pH}$ values at varying topographic elevations. The two transects of the acid sulphate site exhibited lower $\mathrm{pH}$ values as a consequence of an earlier shift to acid sulphate conditions.

Station $1 \mathrm{G}$ was located within a tidal flat $30 \mathrm{~m}$ from the forest fringe. All other stations were established within vegetated areas at least $30 \mathrm{~m}$ from the forest fringe or at least $50 \mathrm{~m}$ from spots where replanted trees had died. Transect 3 was established near a tidal creek to assess its influence on the described parameters, while all other stations were at least $30 \mathrm{~m}$ from tidal creeks.

Topography, inundation regime and forest structure

Topographic elevation (Fig. 1d, e) was determined according to Cohen et al. (2004). Inundation duration at the stations (Fig. 1c) was calculated from measured elevations above mean sea level (MSL) and local tide tables.

For determination of the forest structure, 15 square plots $\left(400 \mathrm{~m}^{2}\right)$ were selected (Table 1). One plot was established in each of the forest sectors A, B, C, H, I, J and $\mathrm{K}$. Three plots were established in each of the forest sectors D, E and F. Within the plots, all trees with stem diameters at breast height $(\mathrm{dbh})>2 \mathrm{~cm}$ were identified and the diameter of the trees was recorded using a circumference band (diameter tape) at $1.3 \mathrm{~m}$ above the 
Fig. 1 Study area. a Saigon River Delta (shaded darkgrey) and herbicide spray paths (black lines), 19611971. b Location of the two study sites within the Can Gio Mangrove Biosphere Reserve (CGMBR) of the delta. c Inundation duration. d, e Location and topographic elevation of the sampling stations at the transects of the control site (d) and the acid sulphate site (e). The numbers at the isolines indicate the elevation in meters above mean sea level. The letters $A-K$ mark the different forests sectors, except $\mathrm{G}$, which marks the tidal flat. The combination of a transect number with a letter (e.g., $1 A$ ) gives the stationID. The map in a was provided using a Geographic Information System (GIS) developed by Stellman et al. (2003a, b)
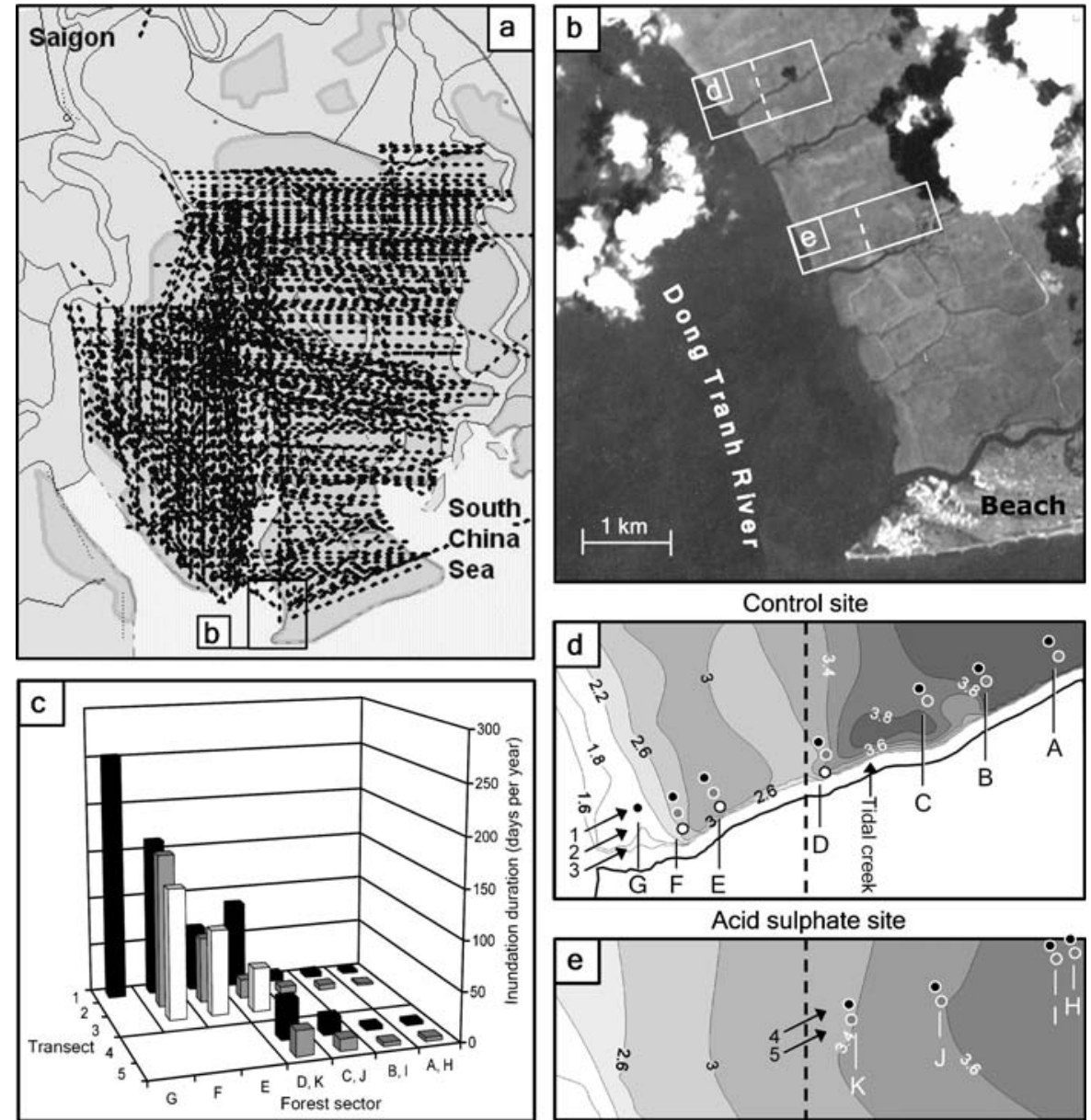

ground or above the highest prop root for Rhizophora. Relative basal area was calculated following Cintrón and Schaeffer-Novelli (1984):

(1) Relative basal area (\%) = basal area of a species $\left(\mathrm{m}^{2}\right) /$ basal area of all species $\left(\mathrm{m}^{2}\right) \times 100$. Basal area $\left(\mathrm{G} ; \mathrm{m}^{2}\right)$ is defined as the cross-sectional area of all trees of a given species.

(2)

$$
\mathrm{G}=\sum_{i=1}^{N} g_{i}
$$

where $g_{\mathrm{i}}\left(\mathrm{m}^{2}\right)$ is the basal area of a single tree.

(3)

$$
\mathrm{g}_{\mathrm{i}}=\pi \times\left(\frac{\mathrm{d}_{\mathrm{i}}}{2}\right)^{2}
$$

where $d_{\mathrm{i}}$ is the dbh at $1.3 \mathrm{~m}$ (in $\mathrm{m}$ ).
Sampling, field measurements and sample preparation

Sediment and leaf sampling took place during the rainy season of 2005. At the stations, a piston-corer was used to take sediment core samples (one core per station; length: $45 \mathrm{~cm}$; diameter: $9 \mathrm{~cm}$ ) immediately after inundation. The corer had sealable inlets for $\mathrm{pH}$ and Eh measurement prior to sectioning.

Physicochemical parameters were measured in the field immediately after sampling of a sediment core. The sediment $\mathrm{pH}$ was measured with a sulphide resistant, sludge suitable SensoLyt SE electrode (WTW, Weilheim, Germany) inserted directly into the center of each core section. The sediment Eh was measured in the same way using two platinum redox micro-probes and an $\mathrm{Ag} / \mathrm{AgCl}$ reference electrode (Microscale Measurements, The Hague, The Netherlands). The functionality of the redox kit (platinum probes, reference electrode and 
Table 1 Some basic parameters at the stations: forest structure, reforestation and spray history, sediment redox potential (Eh) and $\mathrm{pH}$, sediment N:P ratio. Avi Avicennia, Rhi Rhizophora, O. Other genera

\begin{tabular}{|c|c|c|c|c|c|c|c|c|c|c|c|}
\hline \multirow[t]{2}{*}{$\begin{array}{l}\text { Site and } \\
\text { station-ID }\end{array}$} & & \multicolumn{3}{|c|}{$\begin{array}{l}\text { Relative basal } \\
\text { area }(\%)\end{array}$} & \multirow[t]{2}{*}{ Density $^{\mathrm{a}}$} & \multirow[t]{2}{*}{$n>15^{\mathrm{b}}$} & \multirow[t]{2}{*}{ Planted $^{\mathrm{c}}$} & \multirow[t]{2}{*}{ Herbicide $^{\mathrm{e}}$} & \multicolumn{3}{|c|}{$\begin{array}{l}\text { Sediment values } \\
\text { at } 30-35 \mathrm{~cm} \\
\text { depth }\end{array}$} \\
\hline & & $A v i$ & Rhi & $\mathrm{O}$. & & & & & Eh $(\mathrm{mV})$ & $\mathrm{pH}$ & $\mathrm{N}: \mathrm{P}$ \\
\hline \multirow[t]{16}{*}{ Control site } & $1 \mathrm{G}$ & & Absent & & Absent & Absent & Absent & 9,797 (18) & 14 & 7.27 & 5.6 \\
\hline & $1 \mathrm{~F}$ & 96.8 & 3.2 & 0 & 2,875 & 14 & $1978-1986^{\mathrm{d}}$ & 9,797 (18) & -143 & 6.84 & 16.8 \\
\hline & $2 \mathrm{~F}$ & 98.3 & 1.7 & 0 & 3,350 & 16 & $1978-1986^{\mathrm{d}}$ & 9,797 (18) & -71 & 6.75 & 10.6 \\
\hline & $3 \mathrm{~F}$ & 98.5 & 1.5 & 0 & 3,000 & 15 & $1978-1986^{\mathrm{d}}$ & 9,797 (18) & 9 & 6.48 & 14.7 \\
\hline & $1 \mathrm{E}$ & 65.1 & 34.9 & 0 & 5,125 & 11 & $1978-1986^{\mathrm{d}}$ & 9,797 (18) & -124 & 6.44 & 17.4 \\
\hline & $2 \mathrm{E}$ & 80.6 & 19.4 & 0 & 4,900 & 21 & $1978-1986^{d}$ & 9,797 (18) & -23 & 6.51 & 11.8 \\
\hline & $3 \mathrm{E}$ & 92.0 & 8.0 & 0 & 3,725 & 9 & $1978-1986^{\mathrm{d}}$ & 9,797 (18) & -40 & 6.84 & 7.8 \\
\hline & $1 \mathrm{D}$ & 18.5 & 81.5 & 0 & 2,625 & 23 & 1978-1986 & $7,616(13)$ & 27 & 6.26 & 9.7 \\
\hline & $2 \mathrm{D}$ & 20.0 & 76.7 & 3.3 & 1,875 & 20 & 1978-1986 & $7,616(13)$ & 63 & 6.44 & 12.1 \\
\hline & $3 \mathrm{D}$ & 19.6 & 76.8 & 3.6 & 2,725 & 20 & 1978-1986 & $7,616(13)$ & 246 & 6.03 & 8.1 \\
\hline & $1 \mathrm{C}$ & 70 & 030 & 0 & 4150 & 25 & $1078 \quad 1086$ & $7,683(14)$ & -46 & 6.22 & 14.0 \\
\hline & $2 \mathrm{C}$ & 1.0 & 93.0 & 0 & 4,150 & 25 & $19 / 8-1986$ & $7,683(14)$ & 0 & 6.50 & 16.8 \\
\hline & $1 \mathrm{~B}$ & 0 & 100 & 0 & 725 & 10 & 1070 & $7,683(14)$ & 28 & 6.43 & 16.8 \\
\hline & $2 \mathrm{~B}$ & 0 & 100 & 0 & 125 & 10 & $19 / 8-1986$ & $7,683(14)$ & 13 & 6.51 & 9.9 \\
\hline & $1 \mathrm{~A}$ & $N^{f}$ & ND & $N D$ & $\mathrm{ND}$ & ND & $1078 \quad 1086$ & $7,683(14)$ & -19 & 6.64 & 9.3 \\
\hline & $2 \mathrm{~A}$ & & ND & ND & ND & NDD & $19 / 0-1900$ & 7,683 (14) & 10 & 6.71 & 7.1 \\
\hline \multirow{8}{*}{$\begin{array}{l}\text { Acid } \\
\text { sulphate site }\end{array}$} & $4 \mathrm{~K}$ & 03 & 007 & 0 & 675 & 20 & 1078 & $3,144(10)$ & 15 & 5.95 & 34.3 \\
\hline & $5 \mathrm{~K}$ & 9.3 & 90.1 & 0 & $0 / 2$ & 20 & $19 / 8$ & $3,144(10)$ & 40 & 4.67 & 32.2 \\
\hline & $4 \mathrm{~J}$ & 20 & 060 & 0 & 1625 & 2 & 1096 & $4,731(7)$ & 265 & 4.50 & 34.6 \\
\hline & $5 \mathrm{~J}$ & 3.2 & 90.8 & 0 & $1,0<5$ & 3 & 1980 & $4,731(7)$ & 61 & 5.33 & 32.9 \\
\hline & $4 \mathrm{I}$ & 0 & 824 & 176 & 2000 & 0 & 1006 & $6,160(12)$ & 23 & 5.66 & 31.2 \\
\hline & $5 \mathrm{I}$ & 0 & 82.4 & 17.0 & 3,900 & 0 & 1986 & $6,160(12)$ & 78 & 4.94 & 39.5 \\
\hline & $4 \mathrm{H}$ & 0 & 100 & 0 & 2500 & 0 & 1006 & $6,160(12)$ & 169 & 3.49 & 73.1 \\
\hline & $5 \mathrm{H}$ & 0 & 100 & 0 & 5,500 & 0 & 1900 & $6,160(12)$ & 219 & 3.94 & 64.4 \\
\hline
\end{tabular}

${ }^{\mathrm{a}}$ Tree density in number of trees per hectare

${ }^{\mathrm{b}}$ Number of trees with stem diameters at breast height $>15 \mathrm{~cm}$ within a plot

${ }^{\mathrm{c}}$ Dates of tree planting. Data of reforestation history were kindly provided by V.N. Nam (personal communication)

${ }^{\mathrm{d}}$ Plots of subsequent natural regeneration after failed reforestation

${ }^{\text {e }}$ Spray volume in liters of herbicide mixtures in $1 \mathrm{~km}^{2}$ area surrounding station and number of sorties (in parenthesis). Spray history was determined using a GIS developed by Stellman et al. (2003a, b; Stellman and Stellman 2004)

${ }^{\mathrm{f}}$ Not determined

$\mathrm{mV}$-meter) was tested before each field trip by measuring the potentials of $\mathrm{pH} 4.0$ and 7.0 phosphate buffer solutions saturated with quinhydrone. Measurements of $\mathrm{Eh}$ for the $\mathrm{Ag} / \mathrm{AgCl}$ reference electrode were corrected to the standard hydrogen electrode after calculation of the standard potential at the sediment temperature (Pt-100 insertion temperature sensor) for the reference electrode, which contained $3 \mathrm{M} \mathrm{KCl}$. The endpoint of the redox measurement was monitored by using an A/D-converter and computer to visualize the mV-shift.

Sectioned sediments (5 cm steps; nine samples per core) were split, and the subsamples were kept on ice until sample preparation, which began within a few hours. One subsample was taken for subsequent particle size analysis. The second subsample, used for nutrient analysis, was prepared by the removal of 
visible roots, drying at $37^{\circ} \mathrm{C}$ and grinding with a planetary mill. At least $50 \mathrm{~g}$ dried sample was ground to $<300 \mu \mathrm{m}$ mesh in order to prepare a homogenous sample. Generally, heating soils at low temperatures does not significantly affect available P (e.g., Serrasolses et al. 2008). Further, repeated drying at low temperatures did not significantly change the $\mathrm{P}$ compositions of sediments (Oxmann et al. 2008). Moreover, available $\mathrm{P}$ determined after drying reflects in-situ available $\mathrm{P}$ conditions as shown by significant correlations of leaf $\mathrm{P}$ vs available $\mathrm{P}$ (Boto and Wellington 1983).

At each station, one composite leaf sample $(n=50$ leaves) was collected from the tree closest to the location where the sediment core was taken, together with another pooled sample ( $n=90$ leaves) of three more trees around this position. The leaves of both samples were divided into subsamples by separating them into three size classes by their width: $<2.5 \mathrm{~cm}$ (class 1), 2.5-4.0 cm (class 2), > $4.0 \mathrm{~cm}$ (class 3). Leaves were cleaned with deionized water and tissue paper in order to remove attached salts and other particles. Leaf petioles were removed and the leaves were dried at $60^{\circ} \mathrm{C}$, then ground to $<80 \mu \mathrm{m}$ mesh. The powder was kept in a desiccator.

\section{Analytical methods and procedures}

Particle size was determined by laser diffractometry (LA-300, Horiba, Kyoto, Japan) after field moist, sieved $(<500 \mu \mathrm{m}$ mesh) sediments were dispersed in $1 \%$ sodium hexametaphosphate solution. Sediment humidity was calculated by weight difference before and after drying of the samples at $37^{\circ} \mathrm{C}$. Sediment porewater salinity was measured with a conductivity meter (Tetracon electrode, WTW) in deionized water extracts of the sediments (solid-liquid ratio 1:5) and calculated by taking the sediment humidity into account (Perdomo et al. 1998).

Basic $\mathrm{P}$ analysis of the dried sediment powder included determination of Morgan-P (available P) according to a procedure described by Morgan (1941) and a sequential extraction. The Morgan solution was made by preparing a solution of $100 \mathrm{~g}$ sodium acetate in $950 \mathrm{ml}$ with deionized water. Using an InLab 423 electrode (Mettler Toledo, Greifensee, Switzerland), approximately $30 \mathrm{ml}$ acetic acid $(99.5 \%)$ was added until pH 4.8 was obtained. Deionized water was added to make up a full liter. A $2.5 \mathrm{ml}$ volume of the
Morgan solution was transferred to polyethylene centrifuge tubes containing $0.25 \mathrm{~g}$ sediment. Samples were shaken on a rotary shaker for $30 \mathrm{~min}$ and subsequently centrifuged at $1,000 \mathrm{~g}$ for $5 \mathrm{~min}$. The supernatant solutions were taken up into syringes and filtered through $0.45 \mu \mathrm{m}$ syringe filters (Minisart, Sartorius, Göttingen, Germany). Phosphorus fractionation was performed by sequential extraction of inorganic $\mathrm{P}$ into $\mathrm{Al} / \mathrm{Fe}-\mathrm{P}$ (by $\mathrm{NaOH}$ ) and $\mathrm{Ca}-\mathrm{P}$ (by $\mathrm{H}_{2} \mathrm{SO}_{4}$ ), essentially as suggested by Kurmies (1972) but modifications to the procedure were introduced mainly to enhance sample throughput. This method avoids resorption problems through additional $\mathrm{Na}_{2} \mathrm{SO}_{4}$ extractions and underestimations of $\mathrm{NaOH}$ extractable $\mathrm{P}$ through initial washing steps with $\mathrm{KCl}$ / EtOH solution in order to prevent octacalcium phosphate precipitation during the alkaline extraction of $\mathrm{Al} / \mathrm{Fe}-\mathrm{P}$. The modified procedure had been described in detail by Oxmann et al. (2008). Total inorganic P (TIP) was calculated by summing up Ca$\mathrm{P}$ and $\mathrm{Al} / \mathrm{Fe}-\mathrm{P}$. Calculated values were almost identical to TIP quantified by the method of Legg and Black (1955) as determined for sediment samples $(n=20)$ from the same study area.

Individual $\mathrm{P}$ species were quantified for six sediment samples (G35-40, G40-45, A35-40, A4045, H35-40, H40-45; capital letters mark forest sectors and numbers denote depth ranges in centimeters) using the CONVEX method (Oxmann et al. 2008). This newly developed method enables the quantification of discrete $\mathrm{P}$ forms and has been verified by standard addition of octacalcium phosphate (OCP), hydroxyapatite (HAP), strengite and variscite. Briefly, subsamples of a sediment sample were incubated at different $\mathrm{pH}$ values in $\mathrm{pH}$-adjusted $0.01 \mathrm{M} \mathrm{CaCl}_{2}$ for 7 days, and $\mathrm{P}$ species were determined quantitatively through subsequent sequential extraction. The quantification of discrete $\mathrm{P}$ forms is possible by differential dissolution of Ca-P minerals and desorption of $\mathrm{P}$ through $\mathrm{pH}$ adjustment during the incubation procedure.

To determine total $\mathrm{P}$ content in leaves, $50 \mathrm{mg}$ of each sample was weighed in crucibles and combusted in a furnace at $810^{\circ} \mathrm{C}$ for $2 \mathrm{~h}$. After cooling, $10 \mathrm{ml}$ $\mathrm{HNO}_{3}(20 \%)$ was added to the samples. The crucibles were reheated on a sand bath until the liquid began to boil. Solutions were quantitatively filtered $(\mathrm{GF} / \mathrm{F}$ filters, Whatman, Maidstone, UK) into volumetric flasks by rinsing with deionized water and filling up 
to $100 \mathrm{ml}$. Phosphate concentration was measured according to Murphy and Riley (1962) using a Pharmaspec UV-1700 spectrophotometer (Shimadzu, Kyoto, Japan). This method was calibrated against a NIST apple leaf standard (SRM1515).

Carbon and $\mathrm{N}$ content of the sediment and leaf samples were determined by a $\mathrm{C} / \mathrm{N}$ elemental analyzer (Carlo Erba NA 2100, Milan, Italy) using $10 \mathrm{mg}$ sediment sample and $1 \mathrm{mg}$ leaf sample. For total carbon $\left(\mathrm{C}_{\text {tot }}\right)$ determination, tin cups were used. Organic carbon $\left(\mathrm{C}_{\text {org }}\right)$ was measured in silver cups after removal of carbonate by adding $200 \mu 11 \mathrm{~N} \mathrm{HCl}$ and subsequent drying at $40^{\circ} \mathrm{C}$. The accuracy was determined by measuring standards for leaves (SRM1515) and sediment (Leco 1012, Leco, St. Joseph, MI) after every five samples. Depending on sample sizes and tissue type, the combustion tube was cleaned every 5-15 measurements. Inorganic carbon was determined by subtracting $\mathrm{C}_{\text {org }}$ from $\mathrm{C}_{\text {tot }}$.

All chemicals were analytical grade. Deionized water was used, purified by a Millipore Milli-Q system (Millipore, Bedford. MA). All determinations of nutrient concentrations were duplicated.

\section{Results}

Inundation regime and forest structure

The unvegetated mud flat station $1 \mathrm{G}$ was flooded 254 days per year (Fig. 1c). The reforested stands were subjected to inundation durations ranging from 163 days per year at the fringe sites (sector F) to 2 days per year in the hinterland (sectors $\mathrm{A}$ and $\mathrm{H}$ ). Concerning the inundation regime, an area comparable to that of the acid sulphate site $(\mathrm{H}-\mathrm{K})$ can be defined at the control site $(A-G)$, including only the forest sectors A-D (see dashed line in Fig. 1d for separation). This area is further designated as the standard control site.

At sectors $\mathrm{E}$ and $\mathrm{F}$, natural regeneration took place mainly with species of Avicennia after failed reforestation with seeds and saplings of $R$. apiculata. During the first years of reforestation within the study area, plant establishment had been impeded at the higher elevated forest sectors of the acid sulphate site (V.N. Nam, personal communication). Therefore replantation started later (1986) at forest sectors H, I and $\mathrm{J}$ than at the other sectors (Table 1). Accordingly, only three trees had a dbh of more than $15 \mathrm{~cm}$ at sector $\mathrm{J}$ and no trees of more than $15 \mathrm{~cm}$ were found in plots at sectors $\mathrm{I}$ and $\mathrm{H}$ (Table 1). The average number of trees of more than $15 \mathrm{~cm}$ in diameter was six at the acid sulphate site in comparison to 17 at the control site. Avicennia had the highest relative basal area at sites where inundation duration was comparatively high (Table 1, Fig. 1c). In contrast, Rhizophora dominated in plots of higher topographic elevation.

\section{Basic sediment properties}

Sediment humidity from $0-40 \mathrm{~cm}$ depth was between 40 and $60 \%$ and generally decreased with increasing elevation, while the porewater salinity from $0-40 \mathrm{~cm}$ ranged from 25 to $40 \%$ and generally increased with distance to the Dong Tranh River. Silt was the dominant particle size fraction in all sediments, constituting $80-85 \%$ of the column. Carbonate content in the sediments was below the detection limit at the acid sulphate site, while low but measurable amounts were detected above $\mathrm{pH} 6.2$ at the control site (data not shown). Thus, the buffering capacity through $\mathrm{CaCO}_{3}$ was likely insufficient at most of the investigated forest sectors. The highest carbonate content of $1 \%$ by weight was found at the mud flat station $1 \mathrm{G}$.

\section{Sediment $\mathrm{pH}$}

The $\mathrm{pH}$ of the sediment cores $(0-40 \mathrm{~cm})$ ranged from 5.81 to 7.16 at the control site, and from 4.25 to 5.81 at the acid sulphate site. On average, sediment $\mathrm{pH}$ of all stations at the control site increased with depth, but decreased with depth at the acid sulphate site (Table 2).

At $35-40 \mathrm{~cm}$ depth, the $\mathrm{pH}$ varied between 6.15 and 7.28 at the control site, and between 3.28 and 5.96 at the acid sulphate site. Variations among the different sediment layers were comparatively small and $\mathrm{pH}$ differences among stations were influenced mainly by alkaline sea water at the control site. The acid sulphate site exhibited extremely low $\mathrm{pH}$ values below $0-5 \mathrm{~cm}$ depth.

\section{Sediment Eh}

Average Eh values decreased consistently with depth at both sites. At the surface layer of the control site, 
Table 2 Depth layer comparison of $\mathrm{pH}, \mathrm{Eh}, \mathrm{Ca}-\mathrm{P}$ and $\mathrm{Al} / \mathrm{Fe}-\mathrm{P}$

Average values at the control site

${ }^{\mathrm{b}}$ Average values at the acid sulphate site

${ }^{\mathrm{c}} \mathrm{P}$ decrease from $0-5 \mathrm{~cm}$ to $35-40 \mathrm{~cm}(\%)$

\begin{tabular}{llllc}
\hline Depth & Control Site $^{\mathrm{a}}$ & Acidic Site $^{\mathrm{b}}$ & Control Site $^{\mathrm{a}}$ & Acidic Site $^{\mathrm{b}}$ \\
\hline & $\mathrm{pH}$ & & Eh $(\mathrm{mV})$ & \\
$0-5 \mathrm{~cm}$ & 6.34 & 5.47 & 179 & 367 \\
$35-40 \mathrm{~cm}$ & 6.57 & 4.90 & -13 & 77 \\
& $\mathrm{Ca}-\mathrm{P}\left(\mathrm{mg} \mathrm{g}^{-1}\right)$ & & $\mathrm{Al} / \mathrm{Fe}-\mathrm{P}\left(\mathrm{mg} \mathrm{g}^{-1}\right)$ & \\
$0-5 \mathrm{~cm}$ & 0.12 & 0.11 & 0.33 & 0.34 \\
$35-40 \mathrm{~cm}$ & 0.10 & 0.06 & 0.20 & 0.08 \\
Decrease & 20 & 40 & 40 & 80 \\
\hline
\end{tabular}

the average Eh of all stations was $179 \mathrm{mV}$, while it was $-13 \mathrm{mV}$ at $35-40 \mathrm{~cm}$ depth (Table 2). The acid sulphate site was much more oxidized, with Eh values of $367 \mathrm{mV}$ at the surface layer and $77 \mathrm{mV}$ at 35$40 \mathrm{~cm}$ depth.

The difference in sediment Eh among control site stations was highest at $10-15 \mathrm{~cm}$ depth. At this depth interval, Eh increased from $-145 \mathrm{mV}$ at the forest fringe (sector F) to $165 \mathrm{mV}$ in the hinterland (sector A), reflecting the effect of decreasing inundation duration. Differences in the redox potential among these stations were comparatively small below $30 \mathrm{~cm}$, due to the generally strongly reduced conditions at these depth layers. The standard deviation of the Eh was $75 \mathrm{mV}$ at $35-40 \mathrm{~cm}$ depth in comparison to $170 \mathrm{mV}$ at $10-15 \mathrm{~cm}$ depth (data not shown).

Although the unvegetated mud flat station (1G) was flooded for a longer time than the stations with the highest inundation duration within the forest of the control site (F), Eh at the mud flat station was much higher at any depth, most likely due to its lower $\mathrm{OM}$ content. As expected, aeration of the tidal creek caused another Eh gradient perpendicular to the gradient caused by the inundation. The average Eh values of the whole cores were much higher at the creek stations 3D, 3E, 3F compared to the corresponding stations within the same forest sectors (data not shown).

\section{Ca-P and Al/Fe-P: depth dependency}

Sequential extraction of the sediments revealed that average contents of $\mathrm{Ca}-\mathrm{P}$ and $\mathrm{Al} / \mathrm{Fe}-\mathrm{P}$ at the control and the acid sulphate sites consistently decreased with increasing sediment depth, but the decrease was more pronounced at the acid sulphate site (Table 2). Calcium phosphate decreased from $0-5$ to $35-40 \mathrm{~cm}$ by ca. $20 \%$ at the control site, while it decreased by ca. $40 \%$ at the acidic site. At the control site, $\mathrm{Al} / \mathrm{Fe}-\mathrm{P}$ decreased within the same depth interval by ca. $40 \%$, while it decreased by ca. $80 \%$ at the acidic site. Total inorganic $\mathrm{P}$ decreased from $0-5$ to $35-40 \mathrm{~cm}$ by around $30 \%$ at the control site and by around $70 \%$ at the acidic site. Control and standard control site revealed nearly equal results when compared with the acid sulphate site. Hence, the hypothesis that inundation caused differences among sites can be excluded. The only significant $\mathrm{P}$ increase from the surface to the deepest measured sediments, including 48 values of $\mathrm{Al} / \mathrm{Fe}-\mathrm{P}$ and $\mathrm{Ca}-\mathrm{P}$ at the 24 stations, was observed for the Ca-P fraction of the mud flat sediment $(1 \mathrm{G})$. At this station Ca-P increased drastically (by around $60 \%$ ) with depth.

\section{$\mathrm{Ca}-\mathrm{P}$ and $\mathrm{Al} / \mathrm{Fe}-\mathrm{P}$ : patterns at particular layers}

A significant correlation $(P<0.05)$ was detected for Eh vs Al/Fe-P at the layer of the highest Eh difference among stations (see above), at a depth of 10-15 cm (Table 3). However, depths of 30-35 cm and 35$40 \mathrm{~cm}$ appear to be more relevant for P-related sediment-plant interactions at our sites, since root biomass consistently increased from the surface layer to the deepest layers (30-35 and 35-40 cm depth). Accordingly, correlation coefficients of leaf $\mathrm{P}$ vs available $\mathrm{P}$ also increased consistently with increasing sediment depth (Oxmann 2009). At increased depths, no significant correlation $(P>0.05)$ was observed for $\mathrm{Ca}-\mathrm{P}$ or $\mathrm{Al} / \mathrm{Fe}-\mathrm{P}$ vs Eh (Fig. 2a,d). Calcium-bound $\mathrm{P}$ strongly increased with increasing $\mathrm{pH}$ in the ranges $<4$ and $>6$ and was relatively constant in the $\mathrm{pH}$ range 4-6 (Fig. 2b). The Al/Fe-P fraction increased exponentially with $\mathrm{pH}$ in the range $3.3-$ 6.8 and decreased above pH 6.8 (Fig. 2e). These pH 
Table 3 Coefficients and probability levels for correlations between phosphorus forms and physicochemical parameters. Regressions include both sites $(n=24)$ and correspond to linear fits, except for non-linear regressions of correlations with
$\mathrm{pH}^{\mathrm{c}, \mathrm{d}, \mathrm{e}}$. No significant correlations were detected at $0-20 \mathrm{~cm}$ depth, except Eh vs Al/Fe-P (10-15 cm). All other correlations are given for $30-35 \mathrm{~cm}$ (depth of apparently predominant $\mathrm{P}$ uptake)

\begin{tabular}{|c|c|c|c|c|c|}
\hline & Available P & $\mathrm{Al} / \mathrm{Fe}-\mathrm{P}$ & Ca-P & Eh & $\mathrm{pH}$ \\
\hline Leaf P & $0.79 * *$ & NS & NS & NS & $0.72 * *^{\mathrm{c}}$ \\
\hline Available P & & NS & $0.89 * * *$ & NS & $0.94 * * * c$ \\
\hline $\mathrm{Al} / \mathrm{Fe}-\mathrm{P}$ & & & $0.87 * * * \mathrm{a}$ & $0.91 * \mathrm{~b}$ & $* * * \mathrm{~d}$ \\
\hline Ca-P & & & & NS & $0.87 * * * \mathrm{e}$ \\
\hline Eh & & & & & $-0.75 * *$ \\
\hline
\end{tabular}

* $P<0.05 ;{ }^{* *} P 0.01, * * * P<0.001, N S$ not significant

${ }^{\text {a }}$ Values from alkaline sediments were excluded. See Fig. 3

${ }^{\mathrm{b}}$ Correlation detected only at the control site

${ }^{\mathrm{c}}$ See Fig. 4

${ }^{\mathrm{d}}$ Result of two sample (independent) $t$-test. At the given significance level, A1/Fe-P values in the pH range 6.0-6.8 are significantly higher than at other $\mathrm{pH}$ values. See Fig. 2

e See Fig. 2

dependencies of Ca-P and Al/Fe-P (see also Table 3) are explained by the $\mathrm{P}$ speciation, which is affected by different mineral solubilities and adsorption effects. Phosphorus species contents of the Ca-P and $\mathrm{Al} / \mathrm{Fe}-\mathrm{P}$ fractions from six characteristic sediments (G35-40, G40-45, A35-40, A40-45, H35-40 and H40-45 from sectors $\mathrm{G}, \mathrm{A}$ and $\mathrm{H}$, respectively) are shown in Fig. 2c,f and enable a comparison with the fractionation data (see equal symbols in Fig. 2b,e).

The Al/Fe-P fraction correlated highly significantly with Ca-P $(P<0.001)$, if data from alkaline sediments were excluded (Fig. 3a, Table 3). At sediment $\mathrm{pH}$ values above 7 , amounts of $\mathrm{Al} / \mathrm{Fe}-\mathrm{P}$ were much lower than expected from the high content of Ca-P. Highest values of $\mathrm{Al} / \mathrm{Fe}-\mathrm{P}: \mathrm{Ca}-\mathrm{P}$ were recorded in the $\mathrm{pH}$ range 5.95-6.75 (Fig. 3b).

Available $\mathrm{P}$ and leaf $\mathrm{P}$

Generally, $\mathrm{P}$ contents in leaves of size class 2 gave the most significant correlations with available P (30$35 \mathrm{~cm}$ depth). The amount of $\mathrm{P}$ in the leaves and available $\mathrm{P}$ was highly dependent on the sediment $\mathrm{pH}$, since both increased strongly above $\mathrm{pH} 6$ (Fig. 4a, b). A significant correlation of available $\mathrm{P}$ vs leaf $\mathrm{P}$ (Fig. 4c, Table 3) indicates that the Morgan test is a suitable measure for the determination of $\mathrm{P}$ available for mangrove trees. A highly significant correlation was found for available P vs Ca-P (Fig. 5b, Table 3), whilst Ca-P:available $\mathrm{P}$ correlated negatively with sediment $\mathrm{pH}$ (Fig. 5c). Thus, the Morgan-extractable content of the Ca-P fraction increased with increasing sediment $\mathrm{pH}$. No significant correlation $(P>0.05)$ between $\mathrm{Al} / \mathrm{Fe}-\mathrm{P}$ and available $\mathrm{P}$ was found (Fig. 5a).

\section{Sediment $\mathrm{N}$ and leaf $\mathrm{N}$}

In contrast to most nutrient parameters, such as TIP, Ca-P, available $\mathrm{P}$, leaf $\mathrm{P}$ and leaf $\mathrm{N}$, sediment $\mathrm{N}$ contents were negatively correlated $(P<0.001)$ with sediment $\mathrm{pH}$ (Fig. 6a). The $\mathrm{pH}$ dependencies of $\mathrm{N}$ and $\mathrm{P}$ contents in leaves were comparable, since both increased strongly above $\mathrm{pH} 6$ (Fig. 6b). In contrast to the available $\mathrm{P}$ controlled leaf $\mathrm{P}$, leaf $\mathrm{N}$ content was independent of sediment $\mathrm{N}$ content but was significantly correlated $(P<0.001)$ with leaf $\mathrm{P}$ levels (Fig. 6b). Further, N:P ratios in sediments and leaves are apparently affected by $\mathrm{pH}$ (Fig. 6c, d). Figure 7 summarizes the observed interactions of nutrient forms and $\mathrm{pH}$ within the root zone $(30-35 \mathrm{~cm})$.

\section{Discussion}

The focus of this study was on the nutritional aspects of mangrove reforestation. Although available iron and aluminium concentrations were on average ca. $30 \mu \mathrm{mol} / \mathrm{g}$ for both ions at the acid sulphate site, and ca. $1 \mu \mathrm{mol} / \mathrm{g}$ on average for both ions at the control site (data not shown), the increase in iron and aluminium 

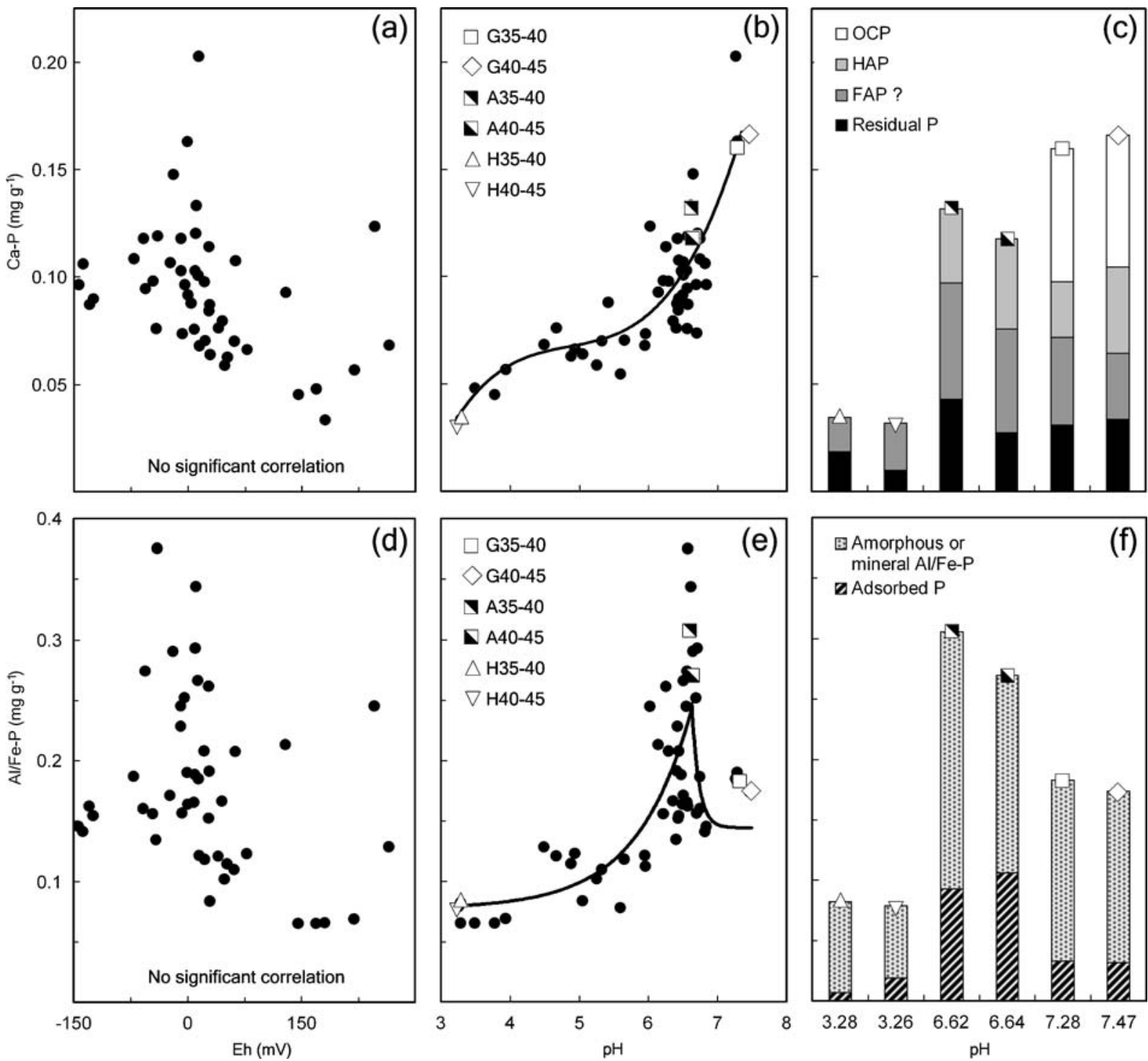

Fig. 2 Phosphorus (P) composition controlled by $\mathrm{pH}$ at deeper sediment layers. a, d Ca-P and $\mathrm{Al} / \mathrm{Fe}-\mathrm{P}$ contents vs field redox 35-40 cm depth) with performed CONVEX analysis are marked separately (see legends). c, f Contents of individual species within the $\mathrm{Ca}-\mathrm{P}$ and $\mathrm{Al} / \mathrm{Fe}-\mathrm{P}$ pools of the additional sediments at their field $\mathrm{pH}$ as determined by the CONVEX method (Oxmann et al. 2008) sediment samples from $30-35$ and $35-40 \mathrm{~cm}$ depth (•). Ca-P and $\mathrm{Al} / \mathrm{Fe}-\mathrm{P}$ contents of additional sediments (30-35 and

due to acidification appears not to be critical for mangrove growth. Iron toxicity causes predominantly dysfunctions in crops, and mangroves are characterized by a high tolerance to aluminium. This tolerance is associated directly with aluminium accumulation in the crowns (Rout et al 2001; Foy et al 1978).

The $\mathrm{P}$ and $\mathrm{N}$ contents in both sediment and leaves were affected by the sediment $\mathrm{pH}$ within the layers of high root biomass, and apparently predominant $\mathrm{P}$ uptake (30-35 and 35-40 $\mathrm{cm}$ depth). Available $\mathrm{P}, \mathrm{Ca}-\mathrm{P}, \mathrm{Al} / \mathrm{Fe}-\mathrm{P}$, leaf $\mathrm{P}$ and leaf $\mathrm{N}$ increased strongly above $\mathrm{pH}$, whereas only sediment $\mathrm{N}$ was correlated negatively with sediment $\mathrm{pH}$. No significant correlations of these nutrient parameters with Eh were detected at $30-35$ and 35-40 cm depth. 


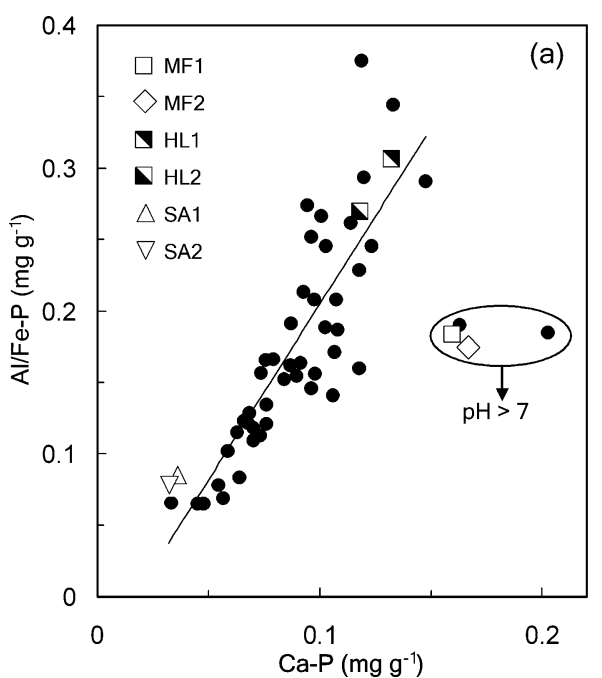

Fig. 3 a Al/Fe-P vs. Ca-P and $\mathbf{b} \mathrm{Al} / \mathrm{Fe}-\mathrm{P}: \mathrm{Ca}-\mathrm{P}$ vs sediment $\mathrm{pH}$ of sediment samples from $30-35$ and $35-40 \mathrm{~cm}$ depth (•). Circled symbols mark data from alkaline sediments. The $\mathrm{pH}$ of the highest Al/Fe-P:Ca-P ratio is marked by an asterisk (6.55), while arrows indicate the $\mathrm{pH}$ range of the peak (5.95-6.75). A

One reason for the lack of correlation between nutrient parameters and Eh seems to be the comparatively small Eh difference among the stations at increased depths. Thus, differences in $\mathrm{P}$ sorption characteristics and mineral compositions at deeper

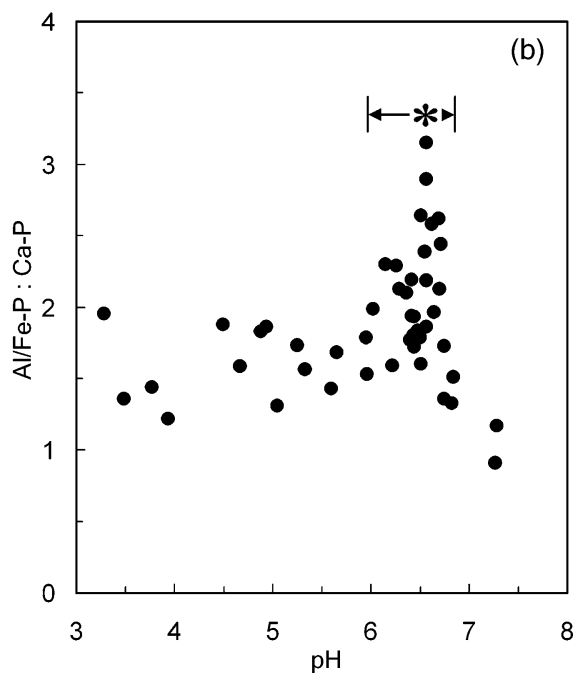

highly significant correlation $(\mathrm{r}=0.87 ; P<0.001)$ was found for $\mathrm{Al} / \mathrm{Fe}-\mathrm{P}$ vs $\mathrm{Ca}-\mathrm{P}$, if values from alkaline sediments were excluded. Data of additional sediments with performed CONVEX analysis are marked separately in a (see legend)

sediment layers seem to be driven by $\mathrm{pH}$ rather than by Eh. Nevertheless, the decline in $\mathrm{Al} / \mathrm{Fe}-\mathrm{P}$ amounts with increasing depth (Table 2), and the significant correlation of $\mathrm{Al} / \mathrm{Fe}-\mathrm{P}$ vs $\mathrm{Eh}$ at a sediment layer of 10-15 cm (Table 3) suggest that the Eh has a certain
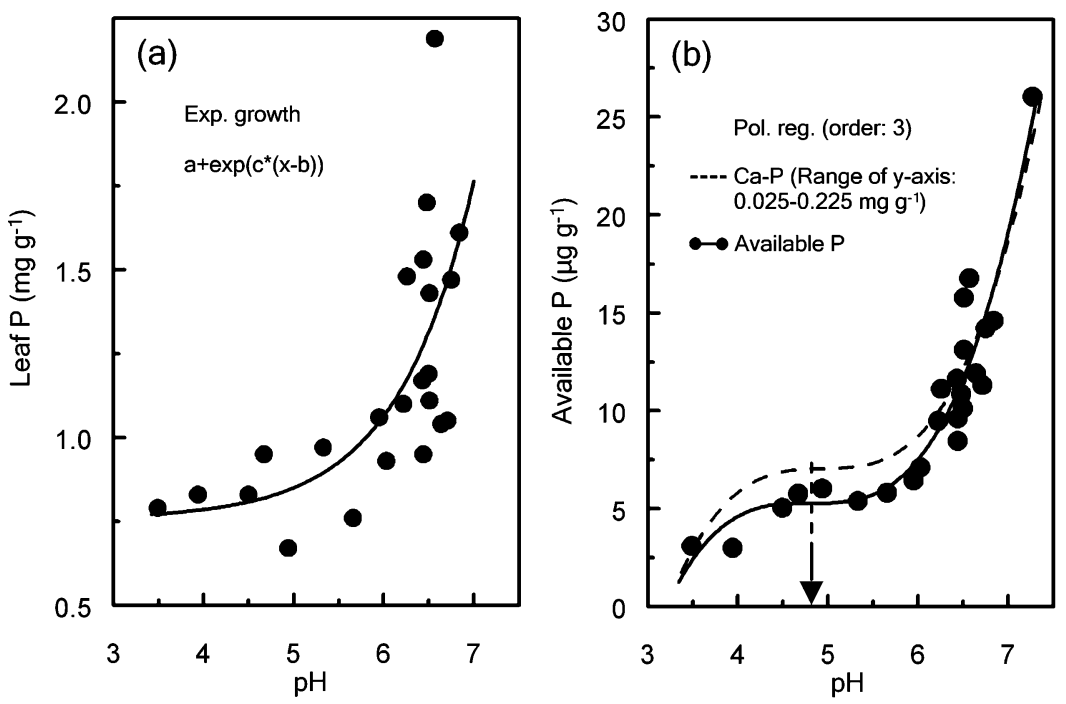

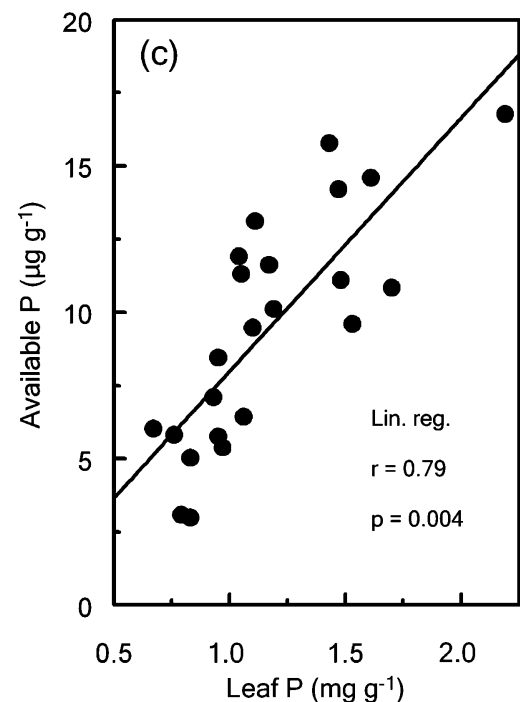

Fig. 4 a Phosphorus content in leaves vs sediment field $\mathrm{pH}$ (30-35 cm depth). Line Exponential growth. b Available $\mathrm{P}$ (Morgan-P) content vs sediment field $\mathrm{pH}(30-35 \mathrm{~cm}$ depth). Lines Polynomial regressions for available $\mathrm{P}$ and $\mathrm{Ca}-\mathrm{P}$ (30$35 \mathrm{~cm}$, cf. Fig. 2b). c A significant correlation of available $\mathrm{P}$ (30-35 cm depth) vs leaf $P$ indicates the suitability of the
Morgan extraction for the determination of $\mathrm{P}$ available for mangrove trees. The $\mathrm{pH}$ value of the Morgan's reagent is marked by an arrow. Note that $\mathbf{c}$ does not contain data points of the alkaline range, since vegetation was absent at the alkaline station (1G) 

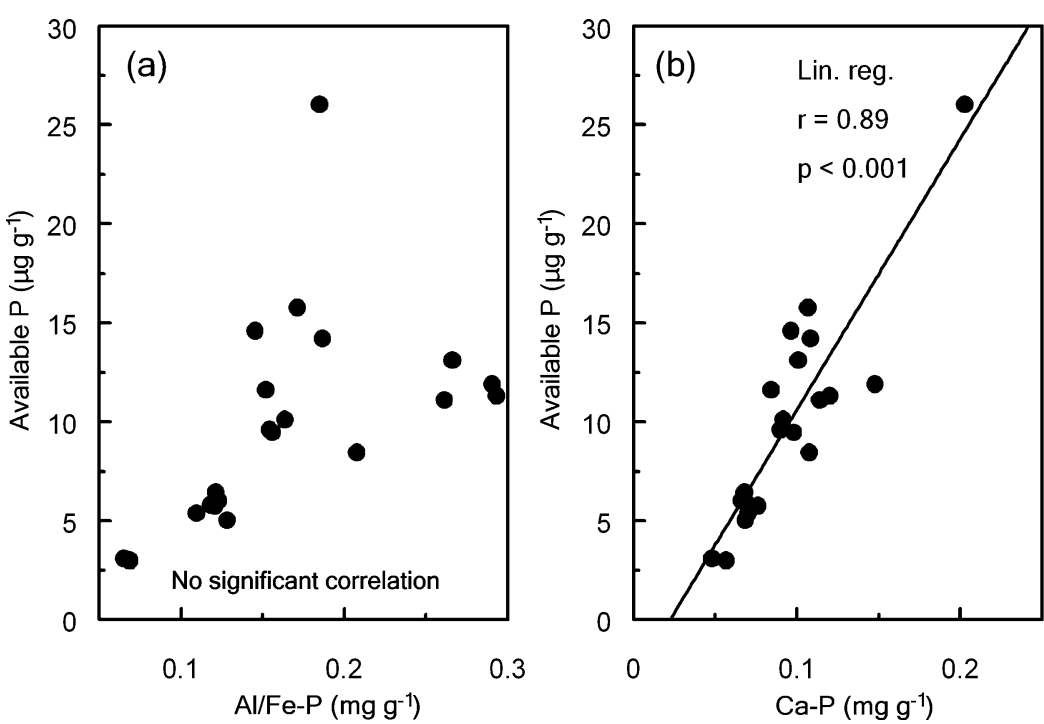

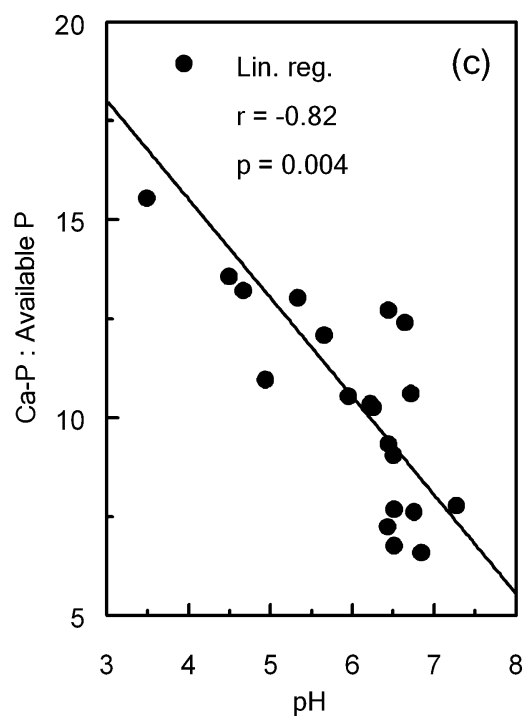

Fig. 5 a Available $\mathrm{P}$ (Morgan-P) vs $\mathrm{Al} / \mathrm{Fe}-\mathrm{P}$ of sediment samples from $30-35 \mathrm{~cm}$ depth. b Available $\mathrm{P}$ vs Ca-P of sediment samples from $30-35 \mathrm{~cm}$ depth (see comparable $\mathrm{pH}$ dependency of Ca-P and available $\mathrm{P}$ in Figs. $2 \mathrm{~b}$ and $4 \mathrm{~b}$ ). c
Ca-P:available P vs sediment $\mathrm{pH}$ at $30-35 \mathrm{~cm}$ depth. Data for linear regression are shown. For these correlations, the values of the creek stations $(3 \mathrm{D}, 3 \mathrm{E}, 3 \mathrm{~F})$ were excluded

fluorapatite (FAP; not verified by standard addition), while HAP was additionally present in the slightly acidic (A35-40, A40-45) and alkaline (G35-40, G40-45) sediments. Only alkaline sediments (G3540, G40-45) contained OCP (Fig. 2c). The quantification of HAP and OCP was verified by standard addition. These data are in agreement with the favored formation of less stable phosphate minerals like brushite and OCP in soils with $\mathrm{pH}>6$, reported by Laverdière and Karam (1984). By comparing the CONVEX data with the sequential extraction data (Fig. 2b,c), we suggest that the increase in Ca-P content with $\mathrm{pH}$ in the range $<4$ was caused by increased amounts of FAP, while the formation of HAP caused an exponential increase of Ca-P in the $\mathrm{pH}$ range 4-7. The precipitation of OCP above $\mathrm{pH} 7$ additionally increased the amount of $\mathrm{Ca}-\mathrm{P}$ in the alkaline sediments. Therefore, the $\mathrm{pH}$ dependency of the Ca-P fraction presented in Fig. $2 b$ reflects the decrease in solubility with increasing $\mathrm{pH}$ of all calcium phosphates as well as differences in the solubilities of individual Ca-P mineral species. The strong increase in Ca-P content above $\mathrm{pH} 6$ suggests that the formation of HAP is supported by OCP precipitation through tidal-affected temporary $\mathrm{pH}$ rises. It is reasonable that HAP is formed via an OCP precursor rather than by direct nucleation 
Fig. 6 a Sediment $\mathrm{N}$

(30-35 cm depth; $\square$ ) and total inorganic $\mathrm{P}(30-35$ and 35-40 cm depth; •) vs sediment pH. b Leaf N ( $\square$ ) and leaf $\mathrm{P}(\bullet)$ vs sediment $\mathrm{pH}$ (30-35 cm depth). c Elemental sediment N:P ratio $(30-35 \mathrm{~cm})$ vs sediment $\mathrm{pH}$. Values of the acid sulphate site are marked separately $(\circ)$ in c.

d Elemental leaf $\mathrm{N}: \mathrm{P}$ ratio vs sediment $\mathrm{pH}(30-35 \mathrm{~cm})$. Dotted line Transition from $\mathrm{N} / \mathrm{P}$ co-limitation to $\mathrm{P}$ limitation $(\mathrm{N}: \mathrm{P}>16)$ according to Koerselman and Meuleman (1996). The diagonal line in $\mathbf{d}$ indicates that $\mathrm{N}$ limitation (relatively low N:P ratios) may occur only at high $\mathrm{pH}$ values
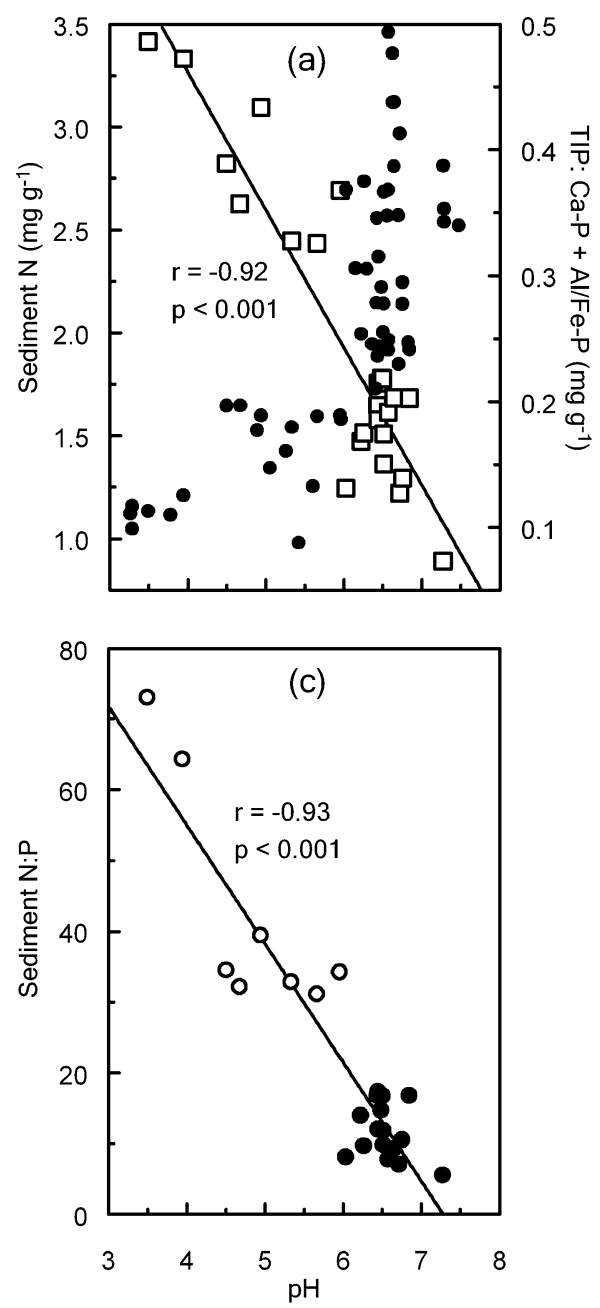
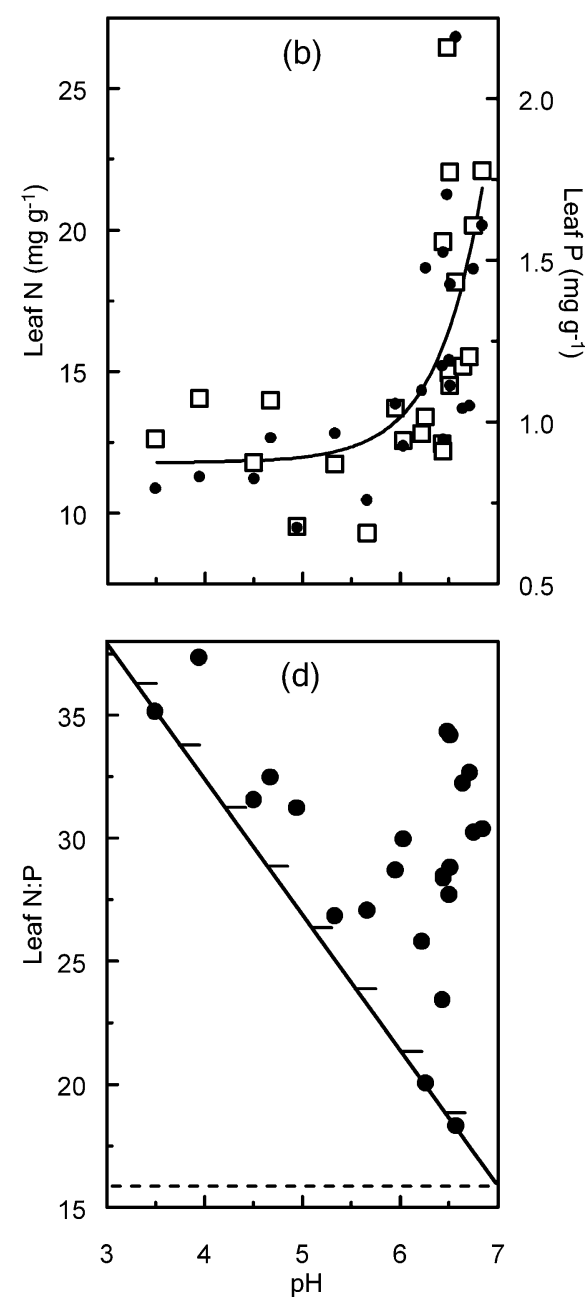

(Gunnars et al. 2004) due to the frequent alkaline seawater input and the slow crystallization rate of HAP (Lindsay et al. 1989) in comparison to OCP.

The high content of $\mathrm{Al} / \mathrm{Fe}-\mathrm{P}$ in the $\mathrm{pH}$ range 6.0 6.8 (Fig. 2e) can be attributed generally to an increased amount of adsorbed $\mathrm{P}$ as shown by comparison with the CONVEX data (Fig. 2f). The slightly acidic sediment contained the highest amounts of adsorbed P, while the strongly acidic sediment consisted mainly of amorphous or mineral Al/Fe-P. Mineral dissolution processes probably resulted in an increased amount of adsorbed $\mathrm{P}$ and consequently in high values of Al/Fe-P:Ca-P within the $\mathrm{pH}$ range 5.95-6.75 (Fig. 3b). Lindsay (1979) suggested the coexistence of several $\mathrm{P}$ minerals in the $\mathrm{pH}$ range 6.0-6.5, in which soils generally reach maximum phosphate solubility (Lindsay et al. 1989). Although different $\mathrm{P}$ minerals may be present, their stability is relatively low in this $\mathrm{pH}$ range and, therefore, the amount of adsorbed $\mathrm{P}$ is likely elevated through the immediate adsorption of dissolved $\mathrm{P}$. Adsorbed $\mathrm{P}$ is probably enhanced by Ca-P dissolution, whereas alternating OCP formation and dissolution could play an important role.

Conversion between OCP and adsorbed P may be highly relevant for rapid $\mathrm{P}$ cycling in sedimentary environments. Alkaline sediments exhibited the highest amounts of $\mathrm{Ca}-\mathrm{P}$, but relatively low amounts of $\mathrm{Al} /$ Fe-P (Figs. 2b,e and 3a) as a consequence of OCP precipitation (Fig. 2c) and less $\mathrm{P}$ adsorption (Fig. 2f). This finding is in agreement with the generally accepted view that there is less adsorbed $\mathrm{P}$ in alkaline than in slightly acidic environments (e.g., Beauchemin et al. 2003). Figure 2c,f shows that OCP and adsorbed $\mathrm{P}$ were the compounds that differed most significantly between slightly acidic and slightly 


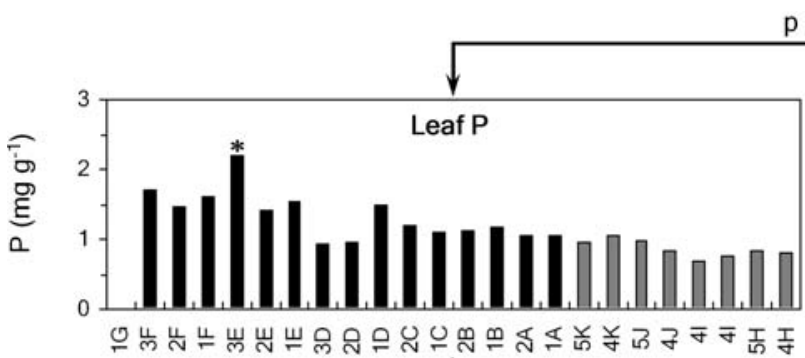

$\mathrm{p}<0.001$
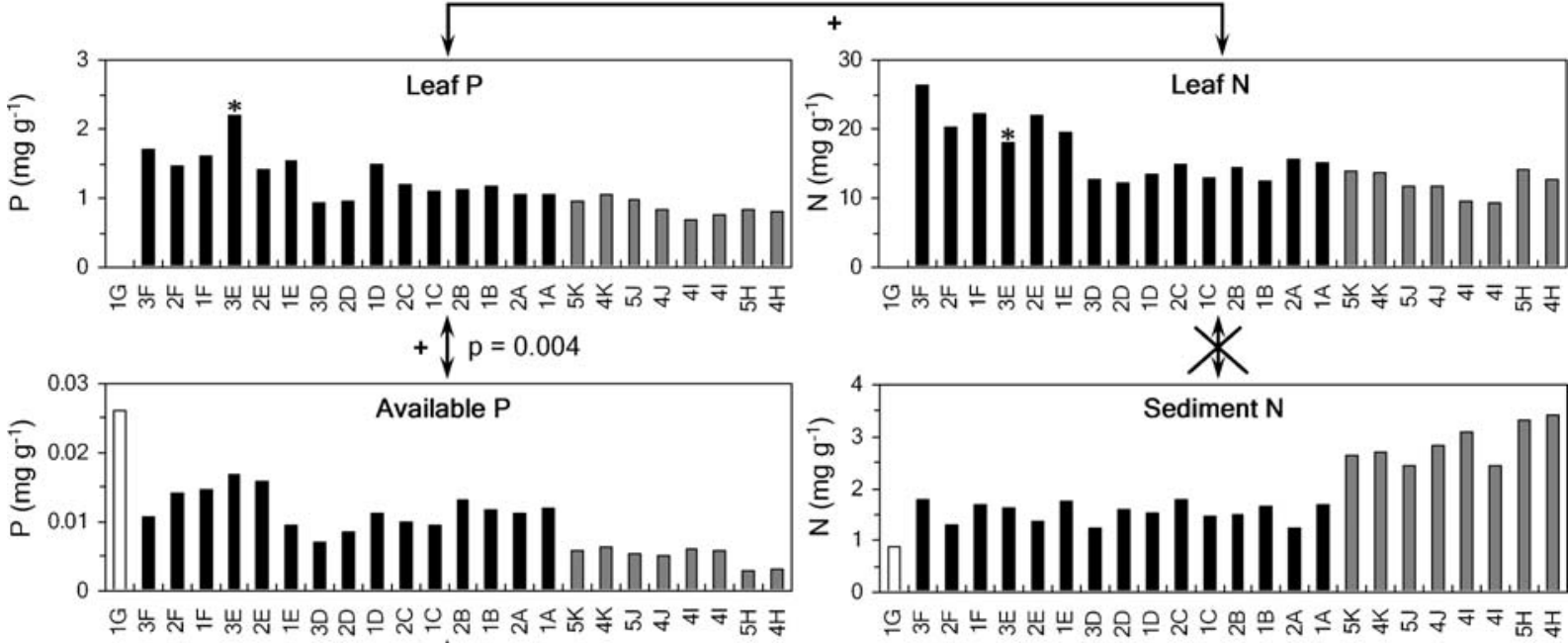

$+\uparrow p<0.001$

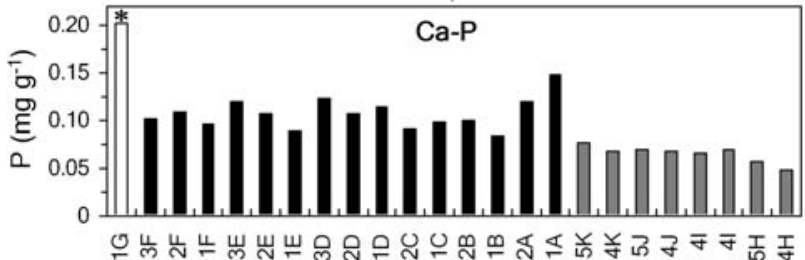

$+\uparrow \mathrm{p}<0.001$
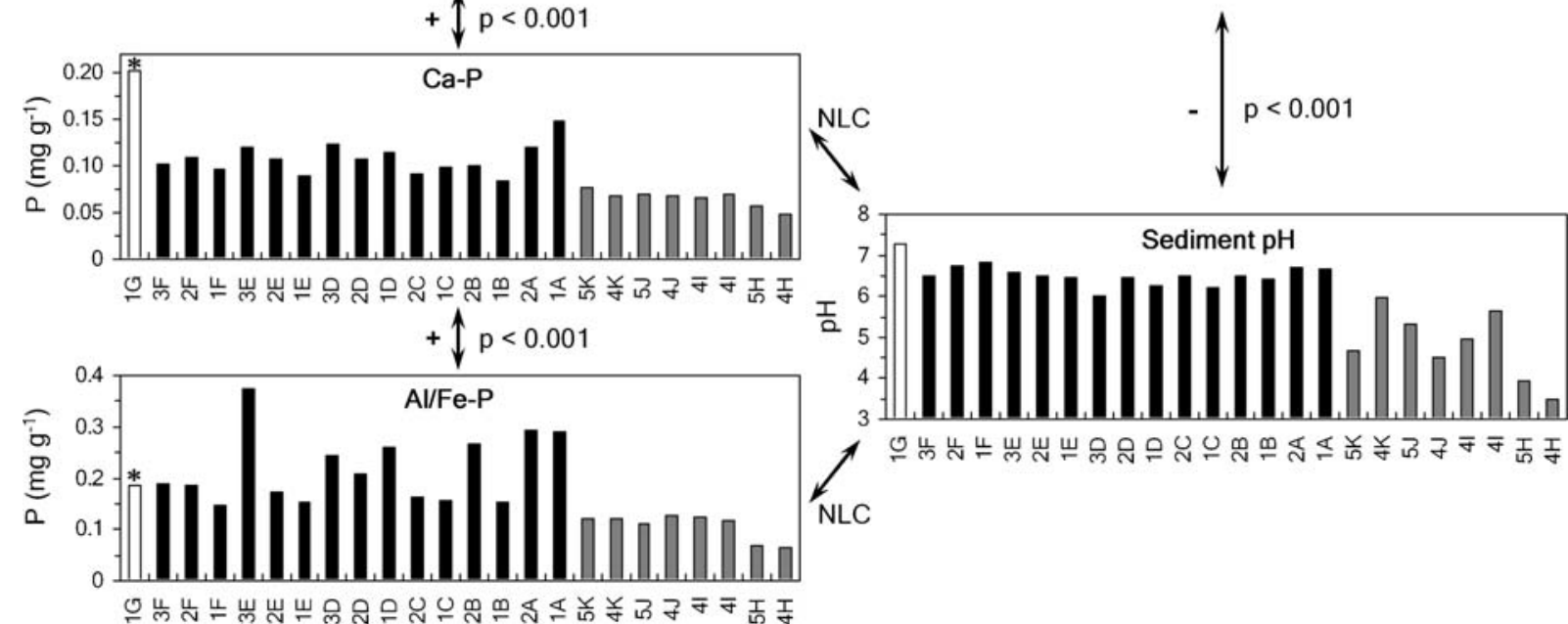

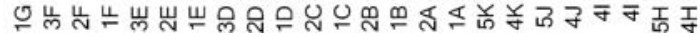

Fig. 7 Proposed primary nutritional control and interactions at the investigated sites. Contents of $\mathrm{Al} / \mathrm{Fe}-\mathrm{P}, \mathrm{Ca}-\mathrm{P}$, available $\mathrm{P}$ (Morgan-P) and sediment $\mathrm{N}(30-35 \mathrm{~cm})$, foliar contents of $\mathrm{P}$ and $\mathrm{N}$ as well as sediment $\mathrm{pH}(30-35 \mathrm{~cm})$ with decreasing inundation duration from stations $1 \mathrm{G}$ to $1 \mathrm{~A}$ (control site) and $5 \mathrm{~K}$ to $4 \mathrm{H}$ (acid sulphate site) are shown. The indirect dependency of leaf $\mathrm{N}$ on available $\mathrm{P}$ indicates $\mathrm{P}$ limitation.

alkaline sediment, suggesting a probable transformation between adsorbed $\mathrm{P}$ and OCP, particularly if tidal effects cause a rapid change in alkaline and acidic conditions and if there is insufficient time for HAP formation through an OCP precursor. This transformation could be especially important for $\mathrm{P}$ availability, because OCP was found to enhance low soluble $\mathrm{P}$ concentrations caused by adsorption (Oxmann et al. 2008).

The strong increase in leaf $\mathrm{P}$ and available $\mathrm{P}$ above pH 6 (Fig. 4a,b) suggests that available P determined
No correlation was found for sediment $\mathrm{N}$ vs leaf $\mathrm{N}$. White bars Sediment values from the mud flat (absent vegetation). Data of positive $(+)$ and negative $(-)$ linear regressions are presented. Data were excluded (asterisks) for Al/Fe-P vs Ca-P (1G, see Fig. 3a) and leaf $\mathrm{P}$ vs leaf $\mathrm{N}$ (3E). See text, Fig. 2b,e and Table 3 for non linear correlations (NLC)

by the Morgan test involves predominantly thermodynamically less stable Ca-P minerals, which seem to be responsible for high $\mathrm{P}$ uptake by plants. This assumption is further supported by a highly significant correlation between available $\mathrm{P}$ and $\mathrm{Ca}-\mathrm{P}$ (Fig. 5b), whereas Ca-P:available $\mathrm{P}$ correlated negatively with sediment $\mathrm{pH}$ (Fig. 5c). In contrast to the dissolution of less stable $\mathrm{Ca}-\mathrm{P}$ species, rapid mineral $\mathrm{Al} / \mathrm{Fe}-\mathrm{P}$ dissolution is unlikely at the $\mathrm{pH}$ used for the Morgan test. Hence, no correlation between Al/Fe-P 
and available P was found (Fig. 5a). This suggests that $\mathrm{Ca}-\mathrm{P}$ is a more effective source of $\mathrm{P}$ available for mangrove tree growth than $\mathrm{Al} / \mathrm{Fe}-\mathrm{P}$. Further, enhanced soluble $\mathrm{P}$ concentrations through OCP dissolution (Oxmann et al. 2008), and highest available $P$ concentrations together with high OCP contents in alkaline sediments imply that OCP is apparently the most effective source for $\mathrm{P}$ plant uptake in the environmental setting investigated here.

In addition to the nutrient content, atomic $\mathrm{N}: \mathrm{P}$ ratios of the sediments were also highly correlated with $\mathrm{pH}$ (Table 1, Fig. 6c). Sediment N:P ratios were much higher at the acid sulphate site than at the control site. As N:P ratios of leaves partly reflected this relationship (Fig. 6d), a shift in limitation could be attributed generally to a shift in sediment $\mathrm{pH}$ within different environmental settings. Further, elemental N:P ratios of leaves were relatively high within all replanted mangrove sectors (Fig. 6d) and likely predict $\mathrm{P}$ limitation (see Koerselman and Meuleman 1996; Lockaby and Walbridge 1998). Particularly at the higher elevated sectors $(\mathrm{H}, \mathrm{I}, \mathrm{J})$ of the acid sulphate site, phosphorus deficiency could be the reason for the initially impeded reforestation and the low diameter values (Table 1).

Our data show that foliar P levels were linked to available $\mathrm{P}$ (Fig. 7). Leaf $\mathrm{N}$ values were indirectly dependent on available $\mathrm{P}$ and independent of sediment $\mathrm{N}$ levels. The amount of available $\mathrm{P}$ was influenced by the sediment $\mathrm{pH}$ as a consequence of the $\mathrm{pH}$-driven Ca-P composition (cf. also Figs. $2 \mathrm{~b}$ and 4b). This suggests that tree growth was limited by $P$, especially at the acid sulphate sectors. Through correlations of $\mathrm{N}$ and $\mathrm{P}$ in sediments and leaves, the deficient nutrient can likely be detected without fertilization studies if the variation in the controlling factor is sufficiently high (Fig. 7). The most relevant restriction for using only vegetation $\mathrm{N}: \mathrm{P}$ ratios for nutrient limitation assessments (Koerselman and Meuleman 1996) seems to be the substrateindependent plant physiological adjustment of vegetation $\mathrm{N}$ and $\mathrm{P}$ concentrations (cf. Fig. $6 \mathrm{a}$ and $\mathrm{b}$ ). Consequently, this $\mathrm{N}: \mathrm{P}$ maintenance led to a less strong foliar N:P correlation with $\mathrm{pH}$ (cf. Fig. $6 \mathrm{c}$ and $\mathrm{d}$ and $\mathrm{N}: \mathrm{P}$ ranges therein).

Comparison of the results presented here with data acquired during the dry season of 2004 (see Oxmann 2009) showed that correlations among nutrient compounds and their dependency on physicochemical parameters were comparable between the seasons. This suggests the high biogeochemical stability of this coastal ecosystem. This stability is probably caused by the effects of the tidal regime and the geomorphological features on the physicochemical parameters, while changes in freshwater input seem to have minor effects within this low-lying area. However, changed biogeochemical conditions caused by severe natural or human impacts seem to be also stable and do not rapidly re-establish through tidal effects.

The depth of the root zone may be decisive in determining whether sediment $\mathrm{Eh}$ or $\mathrm{pH}$ affects $\mathrm{P}$ plant uptake and resulting growth responses in mangroves and similar systems. Phosphorus uptake of saplings may be dependent mainly on variations in Eh, whereas growth of adult mangrove trees, which are generally able to acquire $\mathrm{P}$ from reduced zones at deeper sediment layers, could be affected mainly by sediment $\mathrm{pH}$ changes.

Variations in the Eh could be relevant for withinstand differences in $\mathrm{P}$ availability and composition as well as related plant responses during early reforestation stages, if the sediment $\mathrm{pH}$ is held relatively constant in the slightly acidic range. However, if the $\mathrm{pH}$ increases at the fringe sites, OCP precipitation may provide a significant potential $\mathrm{P}$ source. A strong $\mathrm{pH}$ decrease by pyrite oxidation alters $\mathrm{P}$ cycling fundamentally, and generally causes $\mathrm{P}$ deficiencies. Redox stratification in combination with quantification of different $\mathrm{P}$ forms but without $\mathrm{pH}$ measurement will likely lead to misinterpretation, since variations in both physicochemical parameters produce complex effects on P cycling and composition. Moreover, focusing on physicochemical parameters alone, there is a set of possible interactions. Significant correlations of Eh vs $\mathrm{pH}$ (Table 3) imply that these interactions cause a transition of acidification, in contrast to the distinct definition of acid sulphate soils, which is used to define extreme characteristics caused by pyrite oxidation. Therefore, it is difficult to discriminate whether changes in $\mathrm{Al} / \mathrm{Fe}-\mathrm{P}$ are caused by variations in $\mathrm{pH}$ or Eh, as both parameters affect this fraction directly. On the other hand, changes in the Ca-P fraction are caused directly by variations in $\mathrm{pH}$, which produced extreme changes of $\mathrm{P}$ cycling within the relatively narrow $\mathrm{pH}$ range 6-7. Although Eh had also direct effects besides its interactions with $\mathrm{pH}$, sediment $\mathrm{pH}$ seemed to be the most relevant parameter for direct control of nutrient cycling in reforested mangrove stands. 
Acknowledgments We wish to acknowledge Dr. V.N. Nam for providing information on reforestation history and assistance with site selection. This study was carried out as a part of the German-Vietnamese collaboration project "Can Gio" and was funded by the German Research Foundation.

\section{References}

Beauchemin S, Hesterberg D, Chou J, Beauchemin M, Simard RR, Sayers DE (2003) Speciation of phosphorus in phosphorus-enriched agricultural soils using X-ray absorption near-edge structure spectroscopy and chemical fractionation. J Environ Qual 32:1809-1819

Boto KG, Wellington JT (1983) Phosphorus and nitrogen nutritional status of a northern Australian mangrove forest. Mar Ecol Prog Ser 11:63-69

Cintrón G, Schaeffer-Novelli Y (1984) Methods for studying mangrove structure. In: Snedaker SC, Snedaker JG (eds) The mangrove ecosystem: research methods. UNESCO, Paris, pp 91-113

Cohen MCL, Lara RJ, Szlafsztein CF, Dittmar T (2004) Mangrove inundation and nutrient dynamics under a GIS perspective. Wetl Ecol Manage 12:81-86

Dent DL (1986) Acid sulphate soils: a baseline for research and development. ILRI publications 39, Wageningen

Dent DL, Turner RK (1981) Acid sulphate soils in Broadland, Part II Economic evaluation. BARS 3 Broads Authority, Norwich

Dost H, van Breemen N (1982) Proceedings of the Bangkok symposium on acid sulphate soils. ILRI publications 31 , Wageningen

Feller IC (1995) Effects of nutrient enrichment on growth and herbivory of dwarf Red Mangrove (Rhizophora mangle). Ecol Monogr 65:477-505

Feller IC, McKee KL, Whigham DF, O’Neill JP (2003a) Nitrogen vs. phosphorus limitation across an ecotonal gradient in a mangrove forest. Biogeochemistry 62:145-175

Feller IC, Whigham DF, McKee KL, Lovelock CE (2003b) Nitrogen limitation of growth and nutrient dynamics in a disturbed mangrove forest, Indian River Lagoon, Florida. Oecologia 134:405-414

Foy CD, Chaney RL, White MC (1978) The physiology of metal toxicity in plants. Annu Rev Plant Physiol 29:511-566

Golterman HL (2001) Phosphate release from anoxic sediments or 'What did Mortimer really write?'. Hydrobiologia 450:99-106

Gunnars A, Blomqvist S, Martinsson C (2004) Inorganic formation of apatite in brackish seawater from the Baltic Sea: an experimental approach. Mar Chem 91:15-26

Hart MGR (1959) Sulphur oxidation in tidal mangrove soils of Sierra Leone. Plant Soil 11:215-236

Hirose K, Syoji M, Hang HTM, Anh NH, Triet T, Nam VN (2004) Satellite data application for mangrove management. In: Proceedings of the International Symposium on Geoinformatics for Spatial Infrastructure Development in Earth and Allied Sciences (GIS-IDEAS), Hanoi

Hutchison KJ, Hesterberg D (2004) Dissolution of phosphate in a phosphorus-enriched ultisol as affected by microbial reduction. J Environ Qual 33:1793-1802
Koch MS, Snedaker SC (1997) Factors influencing Rhizophora mangle L. seedling development in Everglades carbonate soils. Aquat Bot 59:87-98

Koerselman W, Meuleman AFM (1996) The vegetation N:P ratio: a new tool to detect the nature of nutrient limitation. J Appl Ecol 33:1441-1450

Kurmies B (1972) Zur Fraktionierung der Bodenphosphate. Die Phosphorsäure 29:118-149

Lara RJ, Szlafsztein CF, Cohen MCL, Oxmann JF, Schmitt BB, Souza Filho PWM (2009) Geomorphology and sedimentology of mangroves and salt marshes: the formation of geobotanical units. In: Perillo GME, Wolanski E, Cahoon D, Brinson M (eds) Coastal wetlands: an integrated ecosystem approach. Elsevier Earth Sciences, Amsterdam

Laverdière MR, Karam A (1984) Sorption of phosphorus by some surface soils from Quebec in relation to their properties. Commun Soil Sci Plant Anal 15:1215-1230

Legg JO, Black CA (1955) Determination of organic phosphorus in soils. 2. Ignition method. Soil Sci Soc Am Proc 19:139-143

Lindsay WL (1979) Chemical equilibria in soils. Wiley, New York

Lindsay WL, Vlek PLG, Chien SH (1989) Phosphate minerals. In: Dixon JB, Weed SB (eds) Minerals in soil environments. Soil Science Society of America, Madison, pp 1089-1130

Lockaby BG, Walbridge MR (1998) Biogeochemistry. In: Messina MG, Connor WH (eds) Southern forested wetlands - ecology and management. Lewis, Boca Raton, pp 149-172

Macdonald BCT, White I, Åström ME, Keene AF, Melville MD, Reynolds JK (2007) Discharge of weathering products from acid sulphate soils after a rainfall event, Tweed River, eastern Australia. Appl Geochem 22:26952705

Morgan MF (1941) Conn Agric Exp Stn Bull 4:450

Murphy J, Riley JP (1962) A modified single solution method for the determination of phosphate in natural waters. Anal Chim Acta 27:31-36

Naidoo G (2006) Factors contributing to dwarfing in the mangrove Avicennia marina. Ann Bot 97:1095-1101

Oxmann JF (2009) Influence of substrate physicochemical properties and organic matter interactions on phosphorus dynamics in replanted mangrove forests, Southern Viet Nam. http://nbn-resolving.de/urn:nbn:de:gbv:46-diss000113248

Oxmann JF, Pham QH, Lara RJ (2008) Quantification of individual phosphorus species in sediment: a sequential conversion and extraction method. Eur J Soil Sci 59:11771190

Paludan C, Morris JT (1999) Distribution and speciation of phosphorus along a salinity gradient in intertidal marsh sediments. Biogeochemistry 45:197-221

Perdomo L, Ensminger I, Espinosa LF, Elster C, WallnerKersanach M, Schnetter ML (1998) The mangrove ecosystem of the Cienaga Grande de Santa Marta (Colombia): Observations on regeneration and trace metals in sediment. Mar Pollut Bull 37:393-403

Roos M, Åström M (2006) Gulf of Bothnia receives high concentrations of potentially toxic metals from acid sulphate soils. Boreal Environ Res 11:383-388 
Rout GR, Samantaray S, Das P (2001) Aluminium toxicity in plants: a review. Agronomie 21:3-21

Serrasolses I, Romanyà J, Khanna PK (2008) Effects of heating and autoclaving on sorption and desorption of phosphorus in some forest soils. Biol Fertil Soils 44:1063-1072

Stellman SD, Stellman JM (2004) Exposure opportunity models for Agent Orange, dioxin, and other herbicides in Vietnam, 1961-1971. J Expo Anal Environ Epidemiol $14: 354-362$
Stellman JM, Stellman SD, Christian R, Weber T, Tomasallo C (2003a) The extent and patterns of usage of Agent Orange and other herbicides in Vietnam. Nature 422:681-687

Stellman JM, Stellman SD, Weber T, Tomasallo C, Stellman AB, Christian R (2003b) A geographic information system for characterizing exposure to agent orange and other herbicides in Vietnam. Environ Health Perspect 111:321328 